\title{
Garra arupi, a new cyprinid fish species (Cypriniformes: Cyprinidae) from upper Brahmaputra basin in Arunachal Pradesh, India
}

\author{
K. Nebeshwar ${ }^{1}$, W. Vishwanath ${ }^{2} \&$ D.N. Das ${ }^{1}$ \\ ${ }^{1}$ Centre of Biodiversity, Rajiv Gandhi University, Rono Hills, Itanagar, India \\ ${ }^{2}$ Department of Life Sciences, Manipur University, Manipur, India \\ Email: ${ }^{2}$ wvnath@gmail.com (corresponding author)
}

\begin{abstract}
Garra arupi, a new cyprinid fish species is differentiated from its congeners along the base of the Himalaya in Brahmaputra basin by a combination of characters: two pairs of barbels, anterior position of vent (vent to anal distance 52.6-60.0\% pelvic to anal distance), a band of 6-9 prominent horny tubercles on the tip of the snout, a submarginal black band on the dorsal fin, and 16 circumpeduncular scales. It is similar to $G$. kempi in having an anterior position of the vent, and similar to $G$. lissorynchus in having a distinct submarginal band on the dorsal fin. Garra arupi differs from G. kempi in having 35-36 (vs. 40-42) lateral line scales, 11-12 (vs. 13-14) predorsal scales, 16 (vs. 12) circumpeduncular scales, the presence of a distinct submarginal band on the dorsal fin (vs. absence), the presence of a transverse band of tubercles on the snout tip (vs. absence), and the presence of 7 8 thin stripes on the caudal peduncle (vs. absence). Garra arupi differs from G. lissorynchus in having 11-12 (vs. 14-15) predorsal scales, 7 (vs. 6) branched dorsal fin rays, 5 (vs. 4) branched anal fin rays, the absence of a W-shaped color band on the caudal fin (vs. presence), the absence of a rostral lobe on the snout (vs. presence), the presence of a transverse band of tubercles on the snout tip (vs. absence), and a vent to anal distance 52.660.0 (vs. $37.3-40.2 \%$ ) pelvic to anal distance.
\end{abstract}

Keywords: Arunachal Pradesh, cyprinid, Garra arupi, new species

Date of publication 26 April 2009 ISSN 0974-7907 (online) | 0974-7893 (print)

\section{Editor: M. Arunachalam}

\section{Manuscript details:}

Ms \# 01842

Received 22 August 2007

Final revised received 16 January 2009

Finally accepted 06 March 2009

Citation: Nebeshwar, K., W. Vishwanath\& D.N. Das (2009). Garra arupi, a new cyprinid fish species (Cypriniformes: Cyprinidae) from upper Brahmaputra basin in Arunachal Pradesh, India. Journal of Threatened Taxa 1(4): 197-202.

Copyright: (C K. Nebeshwar, W. Vishwanath\& D.N. Das 2009. Creative Commons Attribution 3.0 Unported License. JoTT allows unrestricted use of this article in any medium for non-profit purposes, reproduction and distribution by providing adequate credit to the authors and the source of publication.

\section{Author Details: See end of article}

Author contribution: W. VISHWANATH The study: Supervision of taxonomy and phylogeny of freshwater fishes of northeastern India. Current paper: Supervised the work and helped in identifying the species. K. Nebeshwar The study: Morphometric study and identification of fish species. Current paper: Detailed examination of specimens and comparison with closely related species to establish the new species. D.N. DAS The study: Exploration fish species in the region. Current paper: Supervision of fish collection and assisted in comparative study.

Acknowledgement: The authors (KNS and DND) are grateful to University Grant Commission (UGC) for financial assistance.
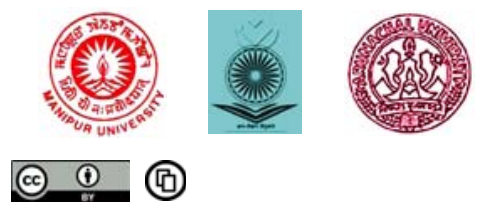

OPEN ACGESS | FREE DOWNLOAD

\section{INTRODUCTION}

The bottom dwelling cyprinid fish genus Garra Hamilton, 1822 consists of approximately 70 species distributed from Borneo to West Africa through southern China, South and Southeast Asia, the Middle East, the Arabian Peninsula, and East Africa (Zhang \& Chen 2002). While revising the genus, Hora (1921) recognized 25 species including seven new species from the Himalayan foothills, viz., G. annandalei from Assam and Darjeeling Himalayas, G. abhoyai and G. naganensis from Manipur, G. prashadi from Uttar Pradesh, G. chaudhurii from northern Bengal, G. jenkinsonianum from Bengal, and G. kempi from Arunachal Pradesh. Other known species from the region are: G. rupecula (McClelland), G. lissorhynchus (McClelland), G. lamta (Hamilton), G. gotyla (Gray), G. nasuta (McClelland) (Hora 1921; Menon 1964). Menon (1964) recognized 38 species under the genus and considered Hora's (1921) G. abhoyai a junior synonym of G. rupecula; G. chaudurii of $G$ annandalei; G. prashadi of G lamta, and G. jenkinsonianum of G. mullya. Nath \& Dey (2000) reported seven species of Garra, viz., G. annandalei, G. gotyla gotyla, G. kempi, G. lamta, G. lissorynchus, G. mcClellandi, and G. naganensis from Arunachal Pradesh. Collections from the Deopani, Ipipani, Sisiri, and Lohit rivers in the Lower Dibang Valley and the Lohit District in Arunachal Pradesh included an undescribed Garra, which is herein described as Garra arupi sp. nov.

\section{Materials and Methods}

The descriptions are based on formalin preserved specimens. Counts, measurements and terminology follow Kullander \& Fang (2004). Measurements were taken point to point with digital calipers to the nearest $0.1 \mathrm{~mm}$. The number in parentheses after a specific count indicates number of specimens examined. Fin rays and number of scales were counted under a zoom stereoscopic microscope. Terminology used for description of disc follows Zhang et al. (2002). Other measurement techniques adopted are as follows: disc width, the widest portion of the lower lip; disc length, length from anterior mid-point of the anterior papillated skin fold to the posterior mid-point of the posterior margin of mental disc; head height, distance from the midline at occiput vertically downward to ventral contour of the breast; lateral line scales, counted from the anteriormost scale in contact with the shoulder girdle to the last scale on the caudal fin; lateral transverse scales above the lateral line, counted from the dorsal fin origin to the lateral line obliquely ventral and caudal and scales below lateral line are counted from the ventral fin origin obliquely dorsal and rostral to lateral line and also from the anal fin origin to the lateral line. Measurements of the head parts are also given in percentages of head length for comparison with data of literature. For vertebral count, eight 
specimens were dissected and stained with alizarin S. Vertebral count includes the first four vertebrae of Weberian apparatus. Abdominal vertebrae were counted from the first four vertebrae of the apparatus to the last vertebra bearing pleural rib and caudal vertebrae, from the vertebra immediately posterior to the anal fin pterygiophore. Types of the comparative materials were physically examined for the study.

\section{Garra arupi sp. nov.}

(Images 1-3; Fig. 1)

\section{Material examined}

Holotype: 60.0mm SL; Deopani River at Roing, Lower Divang Valley, Arunachal Pradesh, India, RGUMF-0 184, Rajiv Gandhi University Museum of Fishes.

Paratype: 49 specimens, all from Arunachal Pradesh, Brahmaputra drainage collected by Nebeshwar and his party during 7-18 February 2007: RGUMF-0185, 15 exs., 50.0$72.4 \mathrm{~mm}$ SL; same data as of holotype; RGUMF-0186, 10 exs. 36.5-69.0mm SL; Iphipani River at Roing, Lower Divang Valley District; RGUMF- 0187, 12 exs., 35.5-65.5 mm SL, Sisiri River at Dambuk, Lower Divang Valley District; RGUMF-0188, 12 exs. 39.5-65.8mm SL, Lohit River at Tezu, Lohit District.

\section{Diagnosis}

Garra arupi sp. nov. is similar to its sympatric species G. kempi in having the anterior position of vent and to G. lissorynchus in having a distinct transverse submarginal band on dorsal fin. The species differs from G. kempi in having 35-36 (vs. 40-42) perforated lateral line scales, vent to anal distance 52.6-60.0 (vs. 50.0-52.9\%) pelvic to anal distance, 11-12 (vs. 13-14) predorsal scales, 16 (vs. 12) circumpeduncular scales, 31/2 (vs. $\left.2^{1 / 2}\right)$ transverse scales between anal fin origin and lateral line, presence (vs. absence) of a distinct submarginal band on the dorsal fin, presence (vs. absence) of a transverse band of tubercles on the snout tip, and the presence (vs. absence) of 7-8 thin stripes on the caudal peduncle. It differs from G. lissorynchus in having 1112 (vs. 14-15) predorsal scales, 7 (vs. 6) branched dorsal fin rays, 5 (vs. 4) branched anal fin rays, $3 \frac{1}{2}$ (vs. $4 \frac{1}{2}$ ) transverse scales between the anal fin origin and the lateral line, absence (vs. presence) of a W-shaped colour band on the caudal fin, absence (vs. presence) of a rostral lobe on the snout, presence (vs. absence) of a transverse band of tubercles on the snout tip, and vent to anal distance $52.6-60.0$ (vs. $37.3-40.2 \%$ ) pelvic to anal distance.

\section{Description}

Measurements and counts of specimens (35.5-72.4mm SL) are given in Table 1. A comparison of the species with its closest congeners is in Table 2. The general appearance of the body is in Image 1, the ventral appearance of body in Image 2, and the morphology of dorsum of head in Image 3. Body elongate, slightly compressed laterally, more on caudal peduncle region. Dorsal profile of body slightly convex from tip of the supraoccipital process to dorsal fin origin. Dorsal fin base almost straight, slightly sloped posteroventrally. Profile from posterior end of dorsal fin base to caudal fin base straight. Ventral profile of body convex from pectoral to pelvic fin origin and straight from pelvic to anal fin origin. Anal fin base nearly straight, posterodorsally inclined. Profile between posterior end of the anal fin base to caudal fin base straight. Head moderately large, depressed with a convex interorbital space; height less than length; width greater than height. Snout broadly rounded with a mere groove across its tip to form a transverse lobe, which contains a band of 6-9 small or large pointed tubercles; 3-5 small lateral tubercles anteroventral to nostrils; 4-12 minute tubercles anteromedially to nostrils, of which 2-4 on each side on the anterosuperior region of nostrils; lateral from the base of rostral barbel having a slightly posteroventrally sloping shallow groove continuous to the lateral groove of rostral cap; rostral lobe absent. Eyes placed dorsolaterally in the posterior half of head.

Two pairs of barbels; rostral ones anterolaterally located, similar to eye diameter; maxillary ones at corner of mouth, shorter than rostral ones. Rostral cap well developed, moderately crenulated, and with a narrow papillated margin; separated from upper jaw by a deep groove and laterally continuous with a distinct antero-lateral lobe of lower lip. No lip in the form of papilliferous tissue along the upper jaw and no papilliferous fold in the corner of mouth. Upper jaw entirely covered by rostral cap. Lower lip modified into a mental adhesive disc. Disc elliptical, shorter than wide and narrower than head width through roots of maxillary barbels; anterior margin modified to form a transverse, fleshy, and crescentic skin fold covered by numerous tiny papillae; anteriorly separated from lower jaw by a groove running along lower jaw and posteriorly bordered in a deep groove with central callous pad; lateral and posterior margin surrounding central callous pad, papillated and free; posteriormost margin extending a little beyond vertical from posterior margin of eye.

Dorsal fin with three (15) simple and seven (15) branched rays; last simple ray shorter than HL; distal margin slightly concave; origin a little nearer to snout tip than caudal fin base, inserted anterior to pelvic fin; first branched ray longest, last branched ray not extending to vertical from anal fin origin. Pectoral fin with one simple and 10 (2), or 11 (13) branched rays, reaching beyond midway to pelvic fin origin; its length shorter than HL; subacuminate margin; fourth branched ray longest, not extending to base of pelvic fin. Pelvic fin with one simple and seven (4) or eight (11) branched rays reaching beyond midway to anal fin origin, surpassing the vent; second branched ray longest, not extending to base of anal fin; origin closer to anal fin origin than to pectoral-fin origin, situated vertically at base of third branched dorsal fin ray; its distal margin almost convex. Anal fin short with three (15) simple and five (15) branched rays; first branched ray longest, straight posterior margin; its tip not reaching base of caudal fin; origin of anal fin closer to caudal-fin base than to pelvic fin origin. Vent slightly closer to pelvic fin origin than to anal fin origin. Caudal fin emarginated; lobe tips slightly pointed; tenth ray shortest; lobes equal in length.

Lateral line complete with $35(6)$ or 36 (9) scales. Scales in transverse row above lateral line $3 \frac{1}{2}(8), 4(4)$, or $4 \frac{1}{2}(3)$ and below lateral line from ventral fin origin $2 \frac{1}{2}(15)$ and from anal fin origin $3 \frac{1}{2}(10), 4(1)$, or $4 \frac{1}{2}(4)$. Circumpeduncular scales 15 (3) or 16 (12). Predorsal scales 11 (10) or 12 (5); scales arranged regularly, same size as flank scales. Chest and belly scaled, embedded under thin skin. An axillary scale at base of pelvic fin nearly reaching its base. Scales between vent and anal-fin base six (1), seven (10), or eight (4) scales. A row of small elongated scales at the base of dorsal fin five (15) and a row of two (5) or three (10) scales at the base of anal fin; all the scales 


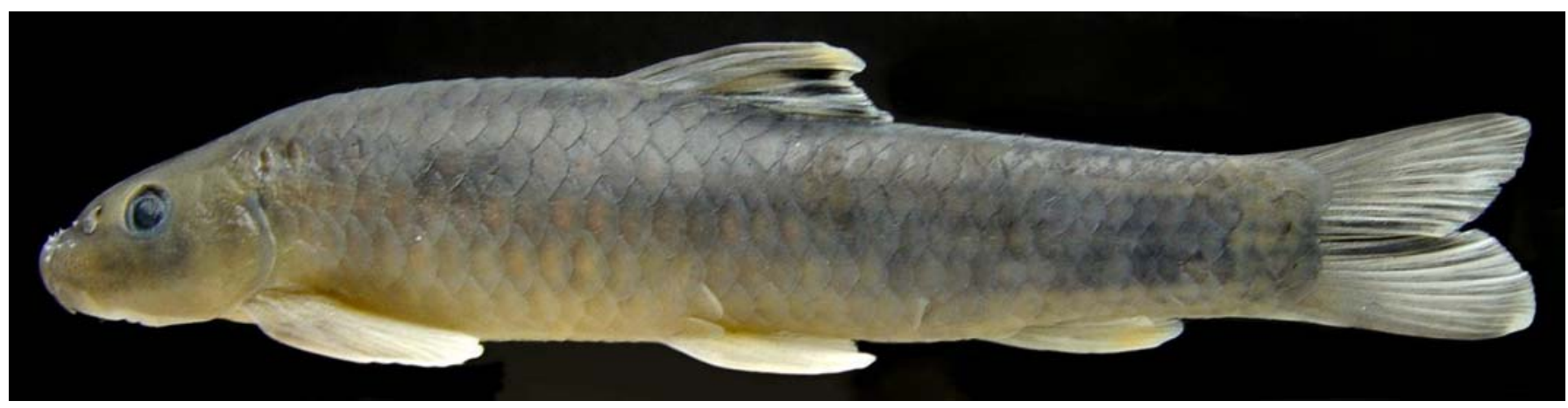

Image 1. Garra arupi sp. nov. Lateral view of holotype RGUMF-0184

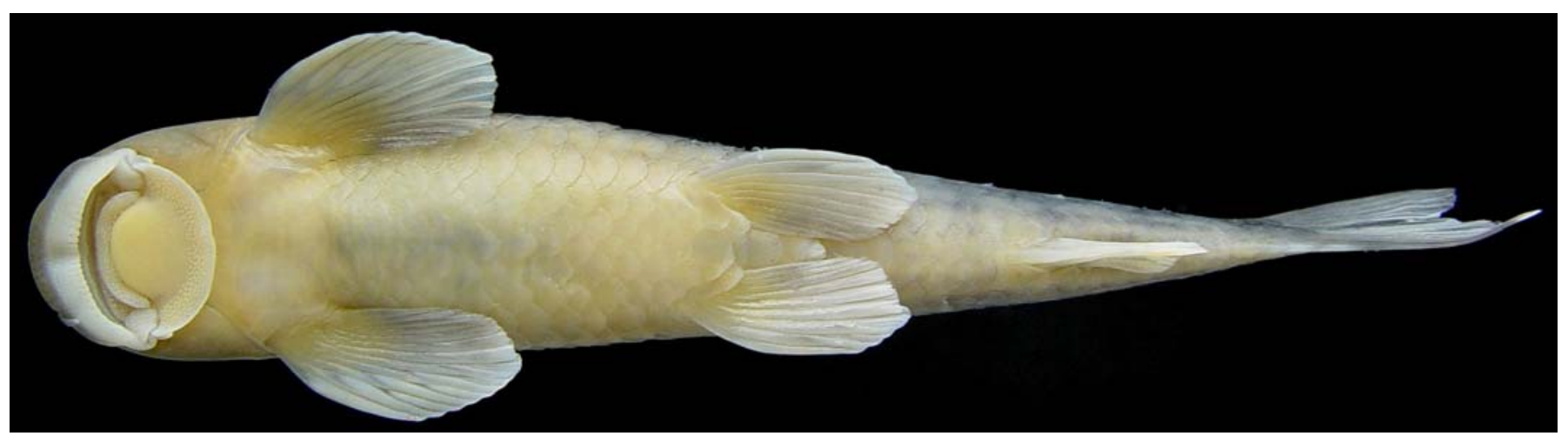

Image 2. Garra arupi sp. nov. Ventral view of holotype RGUMF-0184

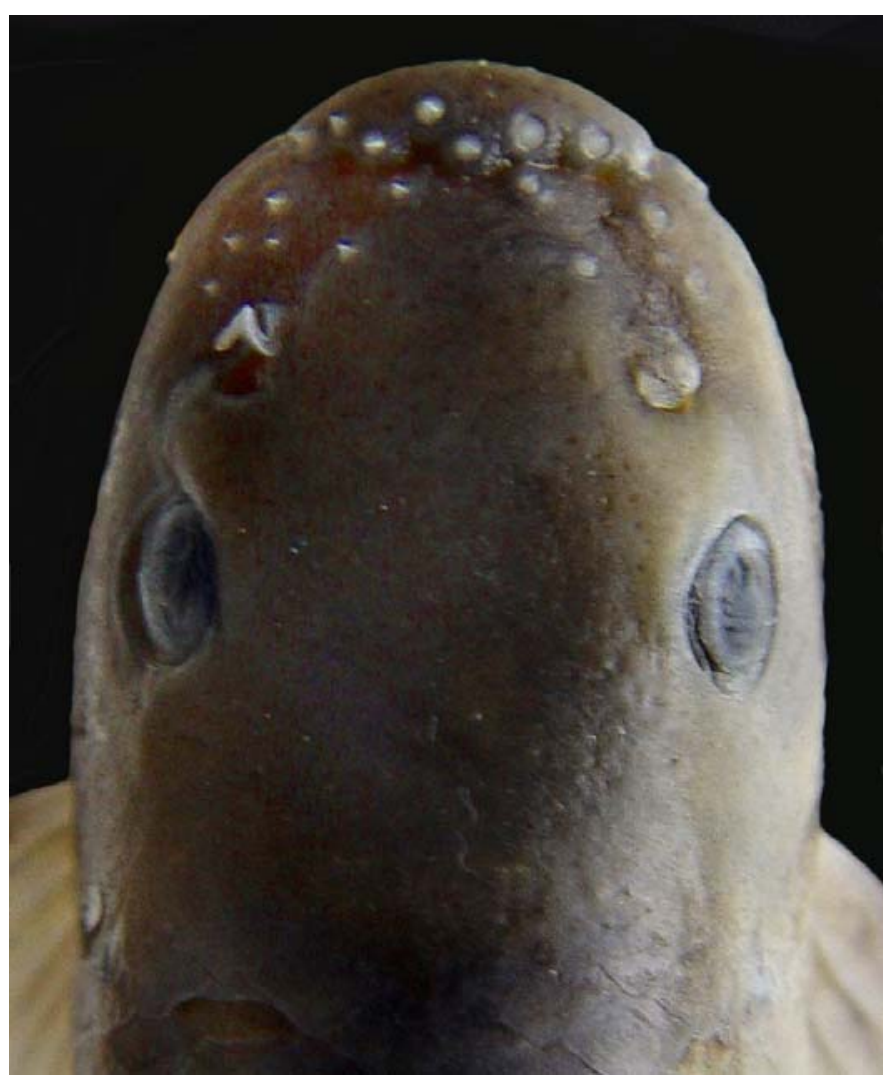

Image 3. Garra arupi sp. nov. Dorsal view of head of holotype RGUMF-0184
Table 1. Morphometric characteristics of Garra arupi sp. nov.

\begin{tabular}{|c|c|c|c|c|}
\hline \multirow[t]{2}{*}{ Morphometrics } & \multicolumn{4}{|c|}{$\begin{array}{c}\text { Garra arupi sp. nov. (49 specimens } \\
\text { including Holotype) }\end{array}$} \\
\hline & Min. & Max. & Mean & S.D. \\
\hline $\begin{array}{l}\text { standard length } \\
\text { In \%SL }\end{array}$ & 50.0 & 72.4 & & \\
\hline body depth & 21.8 & 23.6 & 22.5 & 0.76 \\
\hline head length & 23.3 & 27.5 & 24.8 & 1.31 \\
\hline head height at nape & 15.0 & 17.9 & 16.2 & 0.75 \\
\hline head height at eye & 12.6 & 14.7 & 13.5 & 0.81 \\
\hline head width at opercle & 19.3 & 21.2 & 20.3 & 0.72 \\
\hline head width at nare & 15.7 & 17.9 & 16.9 & 0.70 \\
\hline body width at dorsal & 16.5 & 19.7 & 18.2 & 1.02 \\
\hline body width at anal & 10.1 & 11.5 & 10.9 & 0.53 \\
\hline caudal peduncle length & 15.6 & 17.7 & 16.4 & 0.59 \\
\hline caudal peduncle height & 13.0 & 14.8 & 14.0 & 0.57 \\
\hline dorsal fin length & 19.8 & 23.4 & 21.2 & 1.16 \\
\hline dorsal fin base length & 12.7 & 14.7 & 13.7 & 0.72 \\
\hline pectoral fin length & 20.0 & 23.4 & 21.4 & 1.32 \\
\hline pelvic fin length & 17.1 & 20.2 & 18.5 & 1.05 \\
\hline anal fin length & 15.6 & 19.8 & 17.4 & 1.46 \\
\hline anal fin base length & 6.6 & 8.8 & 7.6 & 0.57 \\
\hline upper caudal fin lobe length & 23.9 & 29.2 & 26.4 & 1.71 \\
\hline lower caudal fin lobe length & 25.4 & 30.3 & 27.3 & 1.56 \\
\hline median caudal fin rays length & 16.9 & 19.8 & 17.9 & 1.03 \\
\hline preanal length & 76.3 & 81.2 & 78.2 & 1.43 \\
\hline pre-anus length & 62.4 & 65.6 & 64.4 & 1.12 \\
\hline preventral length & 51.7 & 54.6 & 52.9 & 0.72 \\
\hline predorsal length & 50.0 & 52.3 & 51.0 & 0.76 \\
\hline prepectoral length & 18.8 & 22.9 & 20.5 & 1.16 \\
\hline In \% ventral-anal length & & & & \\
\hline vent-anal length & 52.6 & 60.0 & 56.1 & 2.20 \\
\hline In \% HL & & & & \\
\hline snout length & 50.0 & 53.2 & 51.5 & 1.22 \\
\hline eye diameter & 20.7 & 27.0 & 23.5 & 1.79 \\
\hline interorbital space & 45.9 & 50.6 & 47.9 & 1.42 \\
\hline disc length & 40.7 & 48.0 & 43.8 & 1.99 \\
\hline disc width & 56.0 & 62.8 & 60.4 & 2.46 \\
\hline callous pad length & 25.7 & 30.0 & 27.7 & 1.50 \\
\hline callous pad width & 35.0 & 40.0 & 38.3 & 1.38 \\
\hline
\end{tabular}


Table 2. Differentiating characteristics of Garra arupi sp. nov. from its closest congeners

\begin{tabular}{|c|c|c|c|}
\hline Characters & Garra arupi sp. nov. & Garra kempi & Garra lissorhynchus \\
\hline $\begin{array}{l}\text { Meristic count } \\
\text { branched dorsal fin rays } \\
\text { branched pectoral fin rays } \\
\text { branched pelvic fin rays } \\
\text { branched anal fin rays } \\
\text { principal caudal fin rays } \\
\text { lateral line scales } \\
\text { lateral transverse scales } \\
\text { predorsal scales } \\
\text { circumpeduncular scales }\end{array}$ & $\begin{array}{l}7 \\
10-11 \\
7-8 \\
5 \\
10+9=19 \\
35-36 \\
31 / 2-41 / 2 / 31 / 2 \\
11-12 \\
15-16\end{array}$ & $\begin{array}{l}7-8 \\
11-12 \\
8 \\
5 \\
9-10+9=18-19 \\
40-42 \\
41 / 2-5 / 21 / 2 \\
13 \\
12\end{array}$ & $\begin{array}{l}6 \\
13 \\
7 \\
4 \\
10+9=19 \\
34-35 \\
31 \frac{1}{2}-41 \frac{1}{2} / 41 \frac{1}{2} \\
14-15 \\
16\end{array}$ \\
\hline $\begin{array}{l}\text { Measurement in \% SL } \\
\text { body depth } \\
\text { caudal peduncle height } \\
\text { dorsal fin length } \\
\text { dorsal fin base length } \\
\text { anal fin base length } \\
\text { pre-anus length } \\
\text { disc width } \\
\text { caudal upper lobe length } \\
\text { caudal lower lobe length }\end{array}$ & $\begin{array}{l}21.8-23.6 \\
13.0-14.8 \\
19.8-23.4 \\
12.7-14.7 \\
6.6-8.8 \\
62.4-65.6 \\
14.4-15.4 \\
23.9-29.2 \\
25.4-30.3\end{array}$ & $\begin{array}{l}20.7-23.1 \\
12.1-13.1 \\
22.3-24.0 \\
13.8-15.3 \\
6.9-8.0 \\
62.8-65.0 \\
14.3-15.4 \\
26.5-29.1 \\
27.4-29.6\end{array}$ & $\begin{array}{l}18.1-20.0 \\
12.8-13.5 \\
18.6-19.7 \\
10.5-12.2 \\
5.6-6.0 \\
67.8-73.1 \\
13.4-14.0 \\
22.5-24.8 \\
22.4-24.4\end{array}$ \\
\hline $\begin{array}{l}\text { In } \% \text { pelvic-anal distance } \\
\text { vent-anal distance }\end{array}$ & $52.6-60.0$ & $48.1-52.9$ & $37.3-40.2$ \\
\hline $\begin{array}{l}\text { a submarginal band on dorsal fin } \\
\text { a transverse band of tubercles on snout tip } \\
\text { stripes on caudal peduncle } \\
\text { W-shaped color band on caudal fin } \\
\text { rostral lobe on snout }\end{array}$ & $\begin{array}{l}\text { present } \\
\text { present } \\
\text { present } \\
\text { absent } \\
\text { absent }\end{array}$ & $\begin{array}{l}\text { absent } \\
\text { absent } \\
\text { absent } \\
\text { absent } \\
\text { absent }\end{array}$ & $\begin{array}{l}\text { present } \\
\text { absent } \\
\text { absent } \\
\text { present } \\
\text { present }\end{array}$ \\
\hline
\end{tabular}

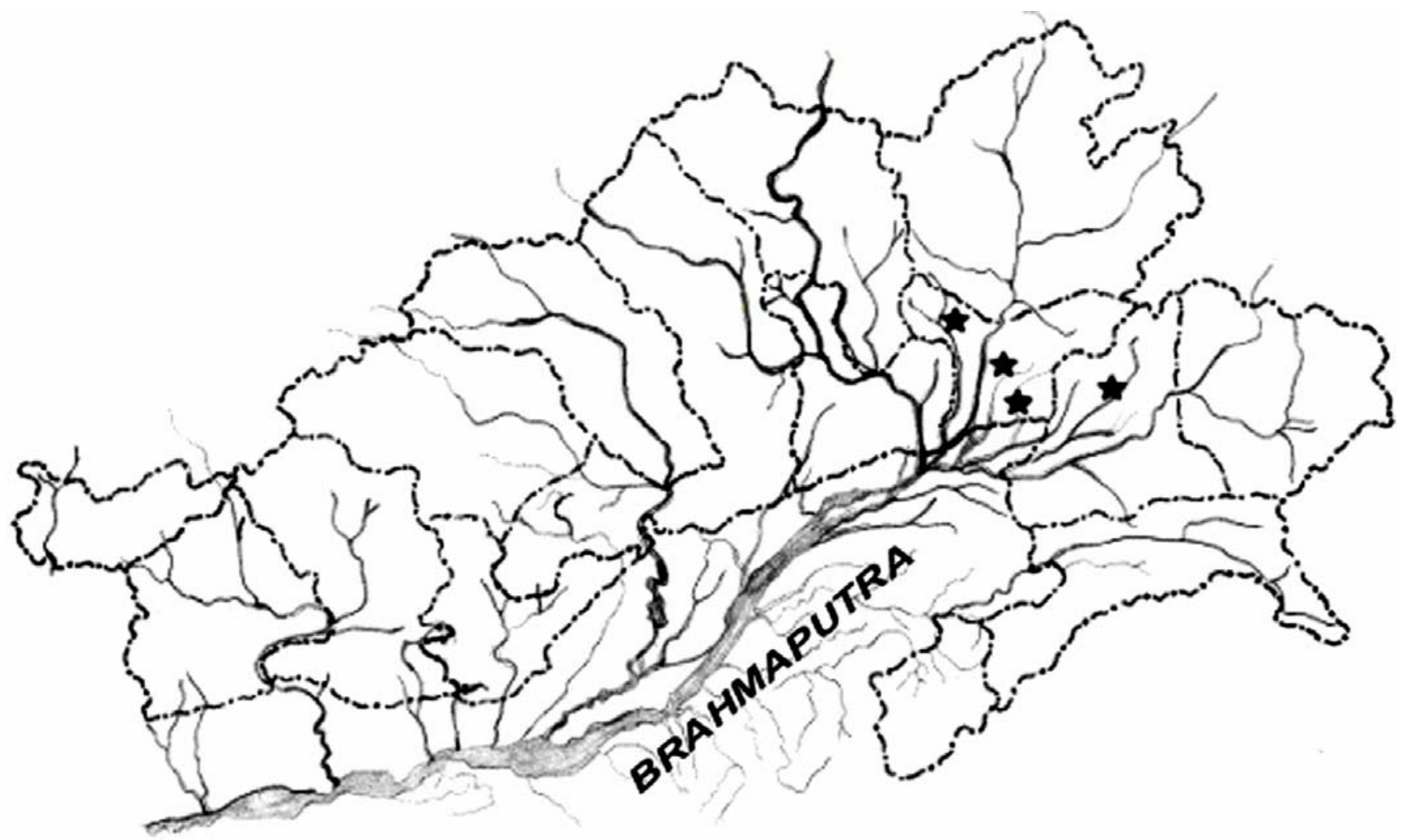

Figure 1. Map showing collection site of Garra arupi sp. nov.

cover the basal region of the fins.

Osteological features

Total vertebrae $35(7), 36$ (1); abdominal $16(6), 17$ (2), predorsal vertebrae $11(7), 12$ (1); caudal 11 (3), 12 (3), 13 (2).

Colour in preservation

Dorsum, sides of head dark brown; head, chest, and abdomen 
whitish or yellowish. All the last six branched dorsal fin rays excluding its distal rim highly spotted with black. These black spots extend anteriorly from its corresponding rays to its distal $1 / 3-1 / 2$ interradial membranes. Whole length of interradial membrane between last simple and $1^{\text {st }}$ branched ray and proximal $2 / s 1 / 2$ and $1 / 3$ length of those between $1^{\text {st }}$ and $2^{\text {nd }}$ branched, $2^{\text {nd }}$ and $3^{\text {rd }}$ branched and $3^{\text {rd }}$ and $4^{\text {th }}$ branched rays covered with elongated membranous flaps, which are gradually tapered distally and originate from their corresponding anterior rays. Seven or eight thin lateral stripes, more in the caudal peduncle region. All the full length of the $9^{\text {th }}$ to $13^{\text {th }}$ rays of caudal fin and outer rays of the dorsal and ventral lobe dark grayish, more on the median. A small rounded black spot at the upper angle of gill opening.

\section{Etymology}

Named in honour of Prof. Arup Kumar Das, Coordinator, UGC sponsored 'Centre of Excellence in Biodiversity', Rajiv Gandhi University, Itanagar.

\section{Distribution}

Garra arupi sp. nov. is known from the upper Brahmaputra basin in the Lower Divang Valley and the Lohit District of Arunachal Pradesh (Fig. 1).

\section{Discussion}

There have been several new descriptions and revisions of Garra species in Asia (Vishwanath \& Sarojnalini 1988; Kosygin \& Vishwanath 1998; Vishwanath \& Kosygin 2000; Kottelat 2000; Gopi 2001; Zhang \& Chen 2002; Kullander \& Fang 2004; Vishwanath \& Shanta 2005; Zhang 2006).

Nath \& Dey (2000) reported the occurrence of Garra naganensis, G. kempi, G. lissorhynchus, G. gotyla, G. annandalei, G. lamta and G. mcClellandi in Arunachal Pradesh. Among them, G. mcClellandi is a peninsular form (Menon 1964; Jayaram 1999). Menon (1964) noted the type locality of G. lamta to be Tinau River, tributary of Rapti River, at Butwal (Nepal) and reported its distribution up to Kumaon Himalaya.

Garra arupi sp. nov. is characteristic in having a shallow groove transversely on its snout tip with a band of 6-9 small or large pointed tubercles. In the specimens having smaller tubercles on the snout tip, there is no such transverse groove. The new species is similar to G. lamta and G. mullya by the presence of a groove on the snout tip. However, G. lamta and G. mullya have a distinct lateral broad stripe and a black blotch on caudal base which $G$. arupi does not have. G. arupi differs from G. lamta in having 35-36 (vs. 31-34) perforated lateral line scales, 11-12 (vs. 8-10) predorsal scales, and vent to anal distance $1.67-1.90$ (vs. 4.00-6.67) in pelvic to anal fin distance. G. arupi further differs from G. mullya in 35-36 (vs. 32-34) perforated lateral line scales, 11-12 (vs. 9-11) predorsal scales, vent to anal distance $1.67-1.90$ (vs. 2.67-3.80) in pelvic to anal fin distance, and $2 \frac{1}{2}$ (vs. 31/2) transverse scales between the pelvic fin and lateral line.

In addition to Garra kempi and G. lissorynchus, there are five species of Garra from the Brahmaputra basin in India, namely $G$. annandalei, G. naganensis, G. gotyla, G. nasuta, and G. rupecula (Menon 1964; Talwar \& Jhingran 1991; Jayaram 1999). G. arupi sp. nov. is separated from them by having a distinct transverse submarginal band on the dorsal fin and an anterior position of the vent. $G$. arupi has a vent to anal distance $52.6-60.0 \%$ pelvic to anal distance (vs. 40.6-44.2 in G. naganensis, 30-33.8 in G. annandalei). G. arupi further differs from Menon's (1964) G. gotyla in having 9-10 (vs. 11-12) predorsal scales, a snout without a proboscis and with a mere transverse groove on snout tip (vs. a snout with a prominent proboscis and a prominent transverse groove on the snout tip), presence (vs. absence) of a black band on branched dorsal fin rays, and an absence (vs. presence) of black spots at the base of branched dorsal fin rays. G. arupi differs from Menon's (1964) G. nasuta in having an absence (vs. presence) of a trilobed proboscis with a distinct transverse groove on the snout tip, anterior position of the vent (vent to anal distance $1.67-1.90$ vs. 3.71-5.25 in pelvic to anal distance), and an absence (vs. presence) of black spots at the base of branched dorsal fin rays.

Garra rupecula McClelland, 1839 was described from the Mishmi Mountains, Assam (now in Arunachal Pradesh) in Brahmaputra basin having the following characteristics: a W-shaped band on the caudal fin and naked scales in the predorsal region (Talwar \& Jhingran 1991), which differentiate it from G. arupi sp. nov. While describing $G$. abhoyai as a new species from the specimens collected from the area of the Ukhrul district in Manipur, Hora (1921) reviewed the description of $G$. rupecula based on fresh specimens collected from the hill streams of Manipur valley, an altogether different river basin. He did not mention significant differentiating characteristics between the two species except for the small body size and presence of pores on the snout in G. rupecula. After decades, Menon (1964) also reviewed the characteristics of G. rupecula based on Manipur valley specimens and put G. abhoyai as its junior synonym. All the streams and rivers draining in the Manipur valley and Ukhrul district belong to Chindwin drainage. Ten specimens (45.0-54.9mm SL) having pores on their snout presently collected from the Iril and Nambul rivers (Chindwin basin) have close similarity with those of Hora (1921) and Menon (1964) mentioned above. The distribution pattern clearly suggests the validity of $G$. abhoyai and absence of G. rupecula in the basin.

Garra abhoyai characteristically has 16-27 small scales embedded in a thin skin on the predorsal region arranged irregularly, with the size of these scales much smaller than those on the flank scales. It has also a narrow black band in the middle of the dorsal fin, a characteristic that G. arupi sp. nov. does not have.

Vishwanath \& Sarojnalini (1988) mentioned the type locality of Garra manipurensis in the Manipur River at Sherou in the Chindwin basin in Manipur. However, several subsequent collections from the type locality did not represent the species. Instead, it is represented in the collections from Tuivai River in the Brahmaputra River basin, Manipur. Thus type locality as given in the original description might be due to wrong labeling. The species has the following combination of characteristics: 4 branched anal fin rays, 13 branched pectoral fin rays, and a rostral lobe which easily differentiates it from G. arupi sp. nov. G. arupi further differs from G. manipurensis in having head height 21.823.6 (vs. 19.2-20.6\% SL), pectoral fin length 20.0-23.4 (vs. 25.3$27.8 \%$ SL), pelvic-fin length $17.1-20.2$ (vs. 21.7-23.4\% SL), preanus length 62.4-65.6 (vs. 68.9-72.4\% SL), disc width 56.0-62.8 (vs. $44.7-52.1 \% \mathrm{SL}$ ), disc length $40.7-48.0$ (vs. $34.6-35.6 \% \mathrm{SL}$ ), callous pad width 35.0-40.0 (vs. 31.9-34.9\%SL), callous pad length 25.7-30.0 (vs. 20.4-2 1.9\% SL), and an anterior position of the vent (vent-anal distance 52.6-60.0 vs. 24.8-29.7\% pelvic to anal distance).

There are four species of Garra from the Chindwin basin in Manipur, namely, G. litanensis, G. paralissorhynchus, G. compressus, and G. elongata (Vishwanath 1993; Kosygin \& Vishwanath 1998; Vishwanath \& Kosygin 2000; Vishwanath \& Shanta 2005). G. 
arupi sp. nov. differs from them in having an anterior position of the vent (vent-anal distance $52.6-60.0$ vs. $25.6-51.8 \%$ pelvic to anal distance). G. arupi further differs from G. elongata and $G$. compressus in having 35-36 (vs. 40-41) perforated lateral line scales, and 16 (vs. 12) circumpeduncular scales. G. arupi differs from $G$. paralissorhynchus in having 35-36 (vs. 32-33) perforated lateral line scales, seven (vs. 6) branched dorsal fin rays, five (vs. 4) branched anal fin rays, and an absence (vs. presence) of a rostral lobe. $G$. arupi differs from $G$. litanensis in the absence (vs. presence) of a proboscis, a presence (vs. absence) of scales on the chest, and seven (vs. 8) branched dorsal fin rays.

There are seven species of Garra from the Irrawaddy River basin in Rakhine Yoma, Myanmar, namely Garra propulvinus, G. vittatula, G. spilota, G. rakhinica, G. flavatra, G. poecilura, and G. nigricollis (Kullander \& Fang 2004). All the species (except G. spilota) share a common character, a rostral lobe on the snout, which can be utilized to separate them from G. arupi sp. nov. G. arupi differs from G. spilota in having the presence (vs. absence) of a submarginal black band on the dorsal fin, an absence (vs. presence) of blotches on the sides, and seven (vs. 8) branched dorsal fin rays.

Kottelat $(1990,2001)$ also remarked that most of the highly specialized rheophilic fish species in Southeast Asia have restricted distribution ranges. So, a thorough revision to present the precise differentiating characteristics and geographical distributions of G. nasuta, G. gotyla, G. rupecula, and Garra mullya would be essential.

\section{Comparative material}

Garra elongata: MUMF 2311, holotype, 86.2mm SL; MUMF 2308-2310, paratype, 3 exs., 72.0- $80.8 \mathrm{~mm}$ SL, a small stream near Tolloi, Ukhrul district, Manipur (Chindwin basin); L. Kosygin, 12 November 1997. - uncatalogued specimen, 4 exs. 63.2$112.5 \mathrm{~mm}$ SL, Challou River at Challou, Ukhrul district, Manipur (Chindwin basin); Kingson, October 2005. - Garra annandalei: RGUMF-0074, 15 exs., 55.3-99.0 mm SL, Kameng River, Balukpung, West Kameng district, Arunachal Pradesh (Brahmaputra basin); Karsen Nyori \& Mrinali Choudhuri, 20 August 2005.- RGUMF-0075, 10 exs., 65.0-85.0mm SL, Panye R., Tamen, Lower Subansiri district; 17 July 2005 - Garra lissorynchus: MUMF 4163-4166, 67.1-86.2mm SL, Iyei River at Noney, Tamenglong district (Brahmaputra basin); K. Nebeshwar, 2 September 2000. - Garra naganensis: MUMF 4156-4159, 4 exs., 92.3-106.9mm SL, Barak River, Vanchengphai Village, Tamenglong district, Manipur (Brahmaputra basin); K. Nebeshwar, 20 November 1999. - uncatalogued specimen, 2 exs., 77.8-84.4 mm SL, Tuivai River, Churchanpur district, Manipur (Brahmaputra basin); K. Shanta Devi, March 2003. \% Garra abhoyai: uncatalogued specimen, 6 exs., 45.2-47.0mm SL, Khujailok stream at Nambol, Bishenpur district, Manipur (Chindwin basin); Vishwanath \& party, April 2001. -uncatalogued specimen, 6 exs., 49.3-54.9mm SL, Iril River at Phungthar, Ukhrul district, Manipur (Chindwin basin); I. Linthoi \& party, 17 January 2003. uncatalogued specimen, 5 exs., 45.0-53.0mm SL, Nambul River at Singda, Imphal district, Manipur (Chindwin basin); Joyshree, 3 February 2004. \%Garra compressus: MUMF 2316, holotype, 68.1mm SL, MUMF 2314-2315; paratype, 2 exs., 78.6-83.2mm SL, Wanze stream at Khamson, Ukhrul district, Manipur (Chindwin basin); L. Kosygin, 17 March 1998. \% Garra paralissorynchus: MUMF 5054, holotype, 65.9mm SL, Khuga River, Churchanpur district, Manipur (Chindwin basin); L. Shanta Devi, 25 july 2000; Paratype: MUMF 5094, 1 ex., 60.9mm SL; 10 April 2000.- MUMF 5041, 1 ex., 58.0mm SL; 3 May 2000- MUMF 5104-5 106, 3 exs., 49.6- 59.6mm SL; 21 August 2002; same collection data as holotype. Garra manipurensis: MU/LSD/F-130, holotype, 59.8mm SL, Manipur River, Sherou, Manipur (Chindwin basin) - MUMF 4160-4162, 3 exs. 41.9-68.3 mm SL, Iyei River, Noney, Tamenglong district (Brahmaputra basin); K. Nebeshwar, 27 December 2000. - Garra kempi: RGUMF-0184, 3 exs., 52.0-56.0mm SL, Egar Stream, Rottung, East Siang district, Arunachal pradesh (Brahmaputra basin); K. Nebeshwar \& party, 12 January 2007.uncatalogued specimen, 2 exs., 64.5-65.0mm SL, Demwe stream, Tezu, Lohit district, Arunachal Pradesh (Brahmaputra basin); K. Nebeshwar \& party, 1 January 2007.

\section{REFERENCES}

Gopi, K.C. (2001). Garra periyarensis, a new cyprinid fish from Periyar Tiger Reserve, Kerala, India. Journal of the Bombay Natural Histry Society 98: 80-83.

Hora, S.L. (1921). Indian cyprinoid fishes belonging to the genus Garra, with notes on related species from other countries. Records of Indian Museum 22: 633-687.

Jayaram, K.C. (1999). The Freshwater Fishes of the Indian Region. Narendra Publishing House, Delhi, $551 \mathrm{pp}$.

Kosygin, L. \& W. Vishwanath (1998). A new cyprinid fish Garra compressus from Manipur, India. Journal of Freshwater Biology 10(1-2): 45-48.

Kottelat, M. (1990). Indochinese Nemacheilines - A Revision of Nemacheiline loaches (Pisces: Cypriniformes) of Thailand, Burma, Laos, Cambodia and Southern Veitnam. Pfeil, Munchen, 262pp.

Kottelat, M. (2000). Diagnosis of a new genus and 64 new species of fishes from Laos (Teleostei: Cyprinidae, Balitoridae, Bagridae, Syngnathidae, Chauduriidae and Tetradontidae). Journal of South Asian Natural History 5: 37-82.

Kottelat, M. (2001). Fishes of Laos. Wildlife Heritage Trust, Colombo, 198pp.

Kullander, S.O., \& F. Fang (2004). Seven new species of Garra (Cyprinidae: Cyprininae) from the Rakhine Yoma, southern Myanmar. Ichthyological Exploration of Freshwaters 15(3): 257-278.

Menon, A.G.K. (1964). Monograph of the cyprinid fishes of the genus Garra, Hamilton. Memoirs of the Indian Museum 14(4): 173-260.

Nath, P. \& S.C. Dey (2000). Fish and Fisheries of North Eastern India (Arunachal Pradesh). Narendra Publishing House, New Delhi, 217pp.

Talwar, P.K. \& A.G. Jhingran (1991). Inland fishes of the India and Adjacent Countries. Oxford \& IBH Publishing Co., New Delhi, 541pp.

Vishwanath, W. \& C. Sarojnalini (1988). A new cyprinid fish, Garra manipurensis, from Manipur, India. Japanese Journal of Ichthyology 35: 124-126.

Vishwanath, W. \& K. Shanta (2005). A new species of the genus Garra HamiltonBuchanan (Cypriniformes: Cyprinidae) from Manipur, India. Journal of the Bombay Natural Histry Society 102(1): 86-88.

Vishwanath, W. \& L. Kosygin (2000). Garra elongata, a new species of the subfamily Garrinae from Manipur, India (Cyprinidae, Cypriniformes). Journal of the Bombay Natural Histry Society 97: 408-414.

Vishwanath, W. (1993). On a collection of fishes of the genus Garra Hamilton from Manipur, India, with description of a new species. Journal of Freshwater Biology 5(1): 59-68.

Zhang, E. \& Y.Y. Chen (2002). Garra tengchongensis, a new cyprinid species from the upper Irrawaddy River basin in Yunnan, China (Pisces: Teleostei). Raffles Bulletin of Zoology 50(2): 459-464.

Zhang, E. (2006). Garra rotundinasus, a new species of cyprinid fish (Pisces: Teleostei) from the upper Irrawaddy River basin, China. Raffles Bulletin of Zoology 54(2): 447-453.

Zhang, E., S.P.He \& Y.Y.Chen (2002). Revision of the cyprinid genus Placocheilus Wu, 1977 in China, with description of a new species from Yunnan. Hydrobiologia 487: 207-217.

\section{Author Details:}

K. NebeSHWAR is Research Associate in UGC sponsored Centre of Biodiversity of Rajiv Gandhi University, Arunachal Pradesh. He is well versed with fish taxonomy and is actively engaged in fish fauna exploration and description of new taxa in the region.

W. VISHWANATH is a Professor in the Department of Life Sciences, Manipur University. His field of specialization is fish and fisheries. He is at present engaged in taxonomy and systematics of freshwater fishes of northeastern India.

D.N. DAS is Reader and Head of Zoology Department of Rajiv Gandhi University, Arunachal Pradesh. He is engaged in fish and fishery teaching and research in the region.

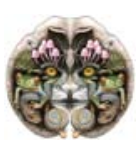

